\title{
ASSESSMENT OF THE ENERGY POTENTIAL OF CROP RESIDUES AND ANIMAL WASTES IN TANZANIA
}

Felichesmi Selestine Lyakurwa Mzumbe University, Tanzania, United Republic of E-mail: felichesmi@gmail.com

Submission: $15 / 04 / 2016$

Revision: 23/06/2016

\section{ABSTRACT}

Accept: 02/07/2016

Energy access has a significant contribution to the social, economic and environmental dimensions of human development. The access to clean and safe energy can improve the human health and quality of ecosystems by reducing the extent of pollution caused by use of inefficient cooking equipment's and processes, and by slowing environmental degradation. In this paper, Monte Carlo simulation was applied to evaluate the amount of crop residues available which provided the basis for the quantity of energy that can be generated from the crop residues and animal wastes in Tanzania. The amount of crop residues and animal wastes was estimated from the agricultural statistical data obtained from the Food and Agriculture Organization of the United Nations (FAO) from 1961 - 2012. The analysis revealed the bioenergy potential of crop residues in Tanzania to be $5,714 \mathrm{TJ}$ in 2012 , which is extremely larger than the installed electric energy generation capacity of 1.564TJ in 2013 . Besides, the estimation of renewable energy potential of live animals indicated the ability to generate 1,397TJ/year if exploited. Thus, effective utilization of crop residues and animal wastes without compromising the amount required for the soil fertility and animal feeds can contribute greatly to the access of safe and clean energy for sustainable development of the rural and urban areas of Tanzania. 
INDEPENDENT JOURNAL OF MANAGEMENT \& PRODUCTION (IJM\&P)

http://www.ijmp.jor.br

v. 7, n. 4, October - December 2016

ISSN: 2236-269X

DOI: 10.14807/ijmp.v7i4.473

Keywords: Energy, Monte Carlo, Crop residues, Animal wastes, Tanzania

\section{INTRODUCTION}

Sustainable development in the world, especially developing countries of Africa and Asia are challenged by access to reliable and clean energy, greenhouse gas emissions (GHG) and high price of fossil fuels (FELIX; GHEEWALA, 2011; SONG, et al., 2014; ZHAO et al., 2016). The world energy council (WEC) documented that, about 1.2 billion of the world population have access to energy and if crucial actions are not taken the number will decrease to 500 million by 2050 (WEC, 2015).

Development of abundant energy sources from both renewable and nonrenewable can provide safe, affordable, reliable and environmental friendly energy that spur the economic growth, social development and universal energy access in developing countries (TAULO, 2015; ISMAIL; KHEMBO, 2015; RAYA, et al., 2016).

To date, agriculture residues have been ascertained to be a potential renewable energy source in different countries of the world, whereby systematic studies were conducted to probe the competing uses of crop residues at the national level (GÓMEZ, et al., 2010; DUKU, et al., 2011; SONG, et al., 2014; MONFORTI, et al., 2015).

For example, the biomass energy accounts for $92 \%$ of the total energy consumption in Tanzania, and projected to dominate the national energy balance. The renewable energy sources such as fuel-wood and agricultural residues used to meet rural energy needs in Tanzania, accounts for the $80 \%$ of the rural energy requirements, while commercial energies such as kerosene, electricity and liquefied petroleum gas contributes about $1 \%$ of the national energy consumption (SHEYA; MUSHI, 2000; FELIX; GHEEWALA, 2011).

Besides, the energy balance of Tanzania indicates an energy shortage, when comparing the installed capacity for electricity production (700MW) and the electricity demand (900MW) which calls a need for development of renewable energy technologies. An interesting story is that, to date, majority of the people especially those residing in the rural areas of Africa depends on wood, animal dung and charcoal for cooking, lighting and warming their bodies. 
INDEPENDENT JOURNAL OF MANAGEMENT \& PRODUCTION (IJM\&P)

http://www.ijmp.jor.br

v. 7, n. 4, October - December 2016

ISSN: 2236-269X

DOI: 10.14807/ijmp.v7i4.473

A simple hypothesis can be, developing countries do not have appropriate technology for value adding on the raw wood/charcoal/animal dung to a more advanced source of energy which is environmental friendly and safe or scientists in africa are thinking of too big technologies that are inappropriate to our geography and forget simple technologies like making an energy efficient "cooking stove", "briquettes charcoal".

Despite the wide use of bioenergy resources in developing countries, including Tanzania, yet information about the supply and the energy potential of agriculture (crop and animal) residues, have not been quantified. Thus, developing a method that can be used to quantify the energy potential of agriculture residues is critical for efficient energy planning and appropriate use of energy resources.

Nevertheless, the traditional bioenergy (i.e., dung, charcoal and firewood) used in Tanzania like other developing countries for domestic (cooking), crop drying, heating of bricks, tobacco production, fish smoking and others, are characterized by low investment, simple technology, large human labour inputs and low energy efficiencies.

The use of traditional bioenergy for various domestic uses by rural and urban population causes the majority of people to suffer from chronic respiratory diseases, difficulty in breathing and stinging eyes, in which young children and their mothers suffer most, and many dies because of indoor air pollution (FELIX; GHEEWALA, 2011).

Hence, developing biogas technologies so as to convert biowaste into renewable energy can improve livelihood of the rural poor, who constitute more than $80 \%$ of the population and reduce human health and environment problems. Comparing with the European and Asian countries that have abundant experience on exploitation of agriculture residues (HU; CHEN, 2013; SONG, et al., 2014; MONFORTI, et al., 2015), Tanzania national level studies about utilization of biomass energy is still at an infant stage, and also the competing uses of agriculture residues are uncertain.

Over the past several years, bioenergy technology has been applied to generate energy from agriculture residues with the use of various types of equipment 
INDEPENDENT JOURNAL OF MANAGEMENT \& PRODUCTION (IJM\&P)

http://www.ijmp.jor.br

v. 7, n. 4, October - December 2016

ISSN: 2236-269X

DOI: 10.14807/ijmp.v7i4.473

in different countries around the world (GÓMEZ, et al., 2010; FERREA, et al., 2011; SONG et al. 2014).

Many studies have been conducted to quantify crop residues available, the energy potential and environmental impact (soil fertility) of crop residue use, that set a solid foundation for the intensive use of agriculture residues (HOU et al., 2009; NZILA et al., 2010; DUKU et al., 2011; MORENOA et al., 2012).

The residue to product ratio (RPR) ratio has been widely used to estimate crop residues generated from different crops (GEHRUNG; SCHOLZ, 2009; BI et al., 2010; BENTSEN et al., 2014; MONFORTI et al., 2015). However, many studies have not considered the uncertainty of crop residues caused by difference in growing conditions, field management and climate, which is seldom to be considered for accurate estimation of crop residues.

In most cases, considering the uncertainty of crop residues, guarantees timely provision of quality information about availability and energy potential of agriculture residues needed for the national energy planning, review of energy policy and effective natural resources management.

To date, several methods have been established to estimate agriculture residues available from crops and animal wastes. Scarlat et al. (2010) and Monforti et al. (2013) established regression models that determine the causal relationships between straw production and grain yields for the main crop residues, used to estimate the total energy available.

The Monte Carlo simulation have been widely applied to establish the amount of agriculture residues under uncertainty, system optimization, risk management and sensitivity analysis (DEBOYS, 2004; JONES, 2008; WOINAROSCHY, 2008). The advantage of Monte Carlos technique over the others is its ability to simulate the uncertainty of repeated random sampling from independent input variables based on the previously known probability distributions. Besides, the simulated results can be presented by histograms whereby all necessary statistical parameters are obtained.

Despite the importance of residues for bioenergy production, yet only few studies conducted to explore the availability of crop residues in Tanzania and none of them considered the uncertainty of crop residues or evaluated the energy potential of crop residues and animal wastes. Hence, the objective of the present study is to 
INDEPENDENT JOURNAL OF MANAGEMENT \& PRODUCTION (IJM\&P)

http://www.ijmp.jor.br

v. 7, n. 4, October - December 2016

ISSN: 2236-269X

DOI: 10.14807/ijmp.v7i4.473

assess the bioenergy potential of crop residues and animal wastes, and evaluate what would be the contribution of biomass energy to the national energy balance.

\section{MATERIALS AND METHODS}

\subsection{Data collection}

The assessment of energy potential of crop residues and animal wastes were built on the statistical data obtained from the food and agriculture organization of the united nations (FAO, 2015). Crop residues can be classified as field or process residues, such that the former refers to residues left in the field after grain harvest and the later constitute byproducts generated in the course of grain processing (COOPER; LAING, 2007; BI et al., 2009; SONG et al. 2014).

This study has considered corncob and rice husks to be process residues and others were considered to be field residues. The number of live animals and crop production were taken as averages over a period of fifty one (51) years, 1961-2012 (FAO, 2015). The assessment covers the animal and crop production from all regions of Tanzania as documented in the faostat database by 2015 (FAO, 2015).

Considering more than $70 \%$ of Tanzanians are agriculturalists, over sixteen number of crops are grown in the area such that the majority of the crops constitutes food crops than cash crops such as coffee, sisal and tea to mention a few (Figure 1).

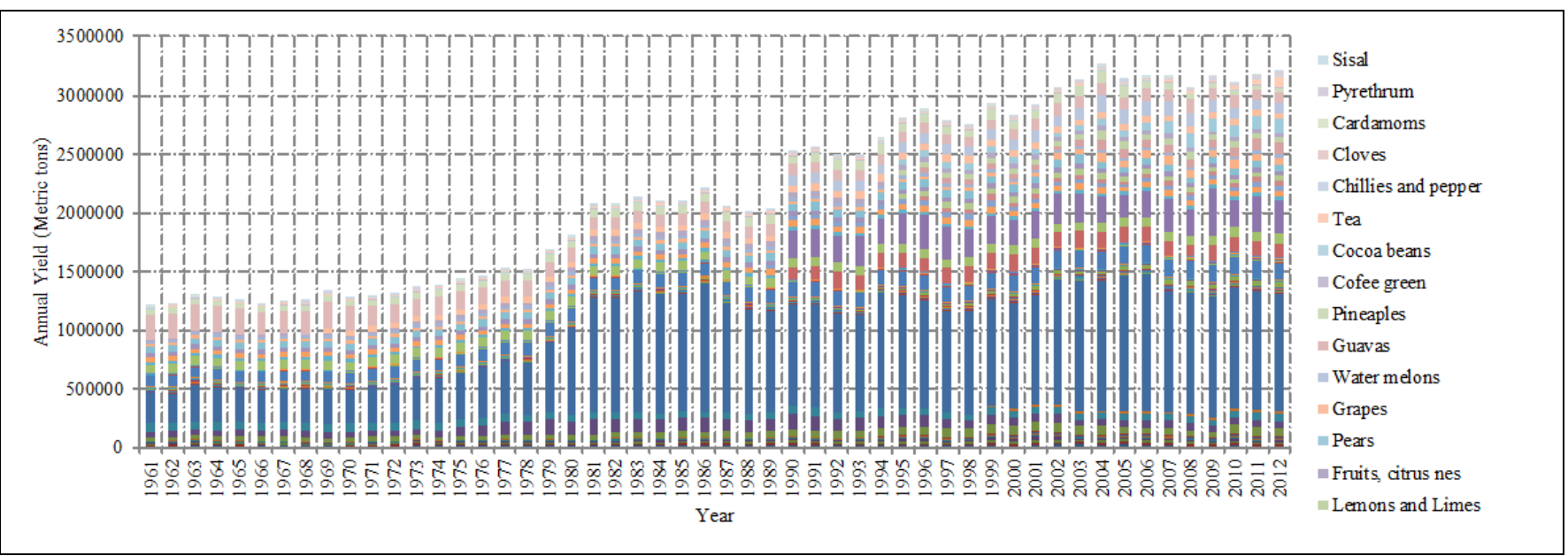

Figure 1: Crop yields in Tanzania $1961-2012$

Source: FAO, 2015

Despite the availability of sixteen crops grown in Tanzania, yet this study have computed crop residues and energy potential of ten (10) crops including wheat, rice, paddy, maize, cassava, tubers, sugar cane, beans, seed cotton, oil seeds and sisal. 
INDEPENDENT JOURNAL OF MANAGEMENT \& PRODUCTION (IJM\&P)

http://www.ijmp.jor.br

v. 7, n. 4, October - December 2016

ISSN: 2236-269X

DOI: 10.14807/ijmp.v7i4.473

Similarly, the energy content of animals wastes were calculated for the four (4) live animals such as cattle, sheep, goats, pigs and poultry (chicken and ducks). The selection of the crops and animals in this study were based on the number, quantity of crops' yield and animal production with respect to their energy potential. The residue to product ratio (RPR) technique was applied to estimate the quantity of residues generated in each year. The rpr of different crops and their respective heating values and standard coal equivalents were obtained from various published literatures (suppoting information SI.1). Besides, the quantity of manure produced by each live animal per day, energy recovery, biomethane potential and heating values of the animal wastes were collected from published literatures (SI. 1).

\subsection{The energy potential of crop residues and animal wastes}

\subsubsection{Computation of energy potential of crop residues}

The quantity of crop residues can be established in different ways based on their potential including technical, theoretical, economic, implementation and sustainable biomass potentials (BIOAMASS ENERGY EUROPE, 2010). The theoretical method is usually the most convenient means for estimation of energy potential as it takes into consideration all the biomass available for various uses e.g., soil nutrient cycling, fodder and energy which can be obtained from the crop production statistics.

Considering the nature of developing countries, not all biomass can be collected and used for energy production due to economic, social, environmental and political concerns. The technical potential is the fraction of theoretically available biomass which are technically recoverable (KEMAUSUOR et al. 2014) and can be used to indicate the optimal renewable energy potential of crop residues without jeopardizing the environment, animal feed and soil quality. This paper therefore, adopted the technical and theoretical concept in establishing the energy potential of crop residues that provide a clue of renewable energy $(\mathrm{MJ})$ to be added into the national energy balance if at all exploited.

The amount of crop residues were computed according to OKELLO et al. (2013) with improvements by considering the uncertainities. The Monte Carlo simulations that has been developed as a standard software of crystal ball oracle 
INDEPENDENT JOURNAL OF MANAGEMENT \& PRODUCTION (IJM\&P)

http://www.ijmp.jor.br

v. 7, n. 4, October - December 2016

ISSN: 2236-269X

DOI: $10.14807 /$ ijmp.v7i4.473

was employed to simulate different values of residue product ratios (RPR) of each crop so as to absorb variations that can affect the quantity of residues generated.

A probability distribution of rpr of the collected data for different crops (Table 1) was simulated and defined as an independent variable to the model. The fitted probability distribution of RPR for each crop and modeling parameters are shown (figure 2), which set a solid foundation for the monte carlo simulation analysis. The amount of crop residues generated were defined as a forecast variables according to model (equation. 1) and rpr probability displayed in Figure 2. Considering the simulation results are influenced by sample numbers, 2000 repeated trials were specified so as to improve the simulation accuracy. The random sampling for monte carlo simulation stops automatically as the accumulated sample number reaches the pre-defined standard.

Table 1: Rpr of crops for different crops derived from published historical data (SI. 1)

\begin{tabular}{lrr}
\multicolumn{1}{c}{ Crop } & Quantity (kg/year) & RPR \\
\hline Wheat & $14,145,327.12$ & $0.67-2.70$ \\
Rice, paddy & $15,386,186.92$ & $0.56-1.53$ \\
Maize & $12,501,760.77$ & $0.55-2.37$ \\
Cassava & $79,210,839.23$ & $0.50-1.00$ \\
Tubers, nes & $20,379,872.14$ & $0.50-1.00$ \\
Sugar cane & $741,346,675.38$ & $0.10-0.52$ \\
Beans dry & $6,456,299.23$ & $1.5-1.7$ \\
Seed cotton & $4,956,671.92$ & $2.22-1.55$ \\
Oil seeds, nes & $5,843,554.81$ & $2.10-2.0$ \\
Sisal & $6,586,075.96$ & $2.40-4.70$ \\
\hline
\end{tabular}

The energy potential of crop residues were computed according to the method proposed by Jiang et al. (2012) with some improvements. The energy potential of crop residues is presented by eq. 1 .

$$
E_{p i}=\sum_{i=1}^{n} Q_{i} * \operatorname{RPR}_{i} * \varepsilon_{i} * L H V_{c}
$$

Where, $E_{\mathrm{pi}}$ is the energy potential of crop residues, $Q_{i}$ represents crop production (kg/year), $\mathcal{E}_{\text {i }}$ presents the standard coal conversion ratio, $L H V$ is the low heating value of the standard coal (BLANCO; LAL, 2009), $n$ presents number of crops, and $i$ is the reference crop. 


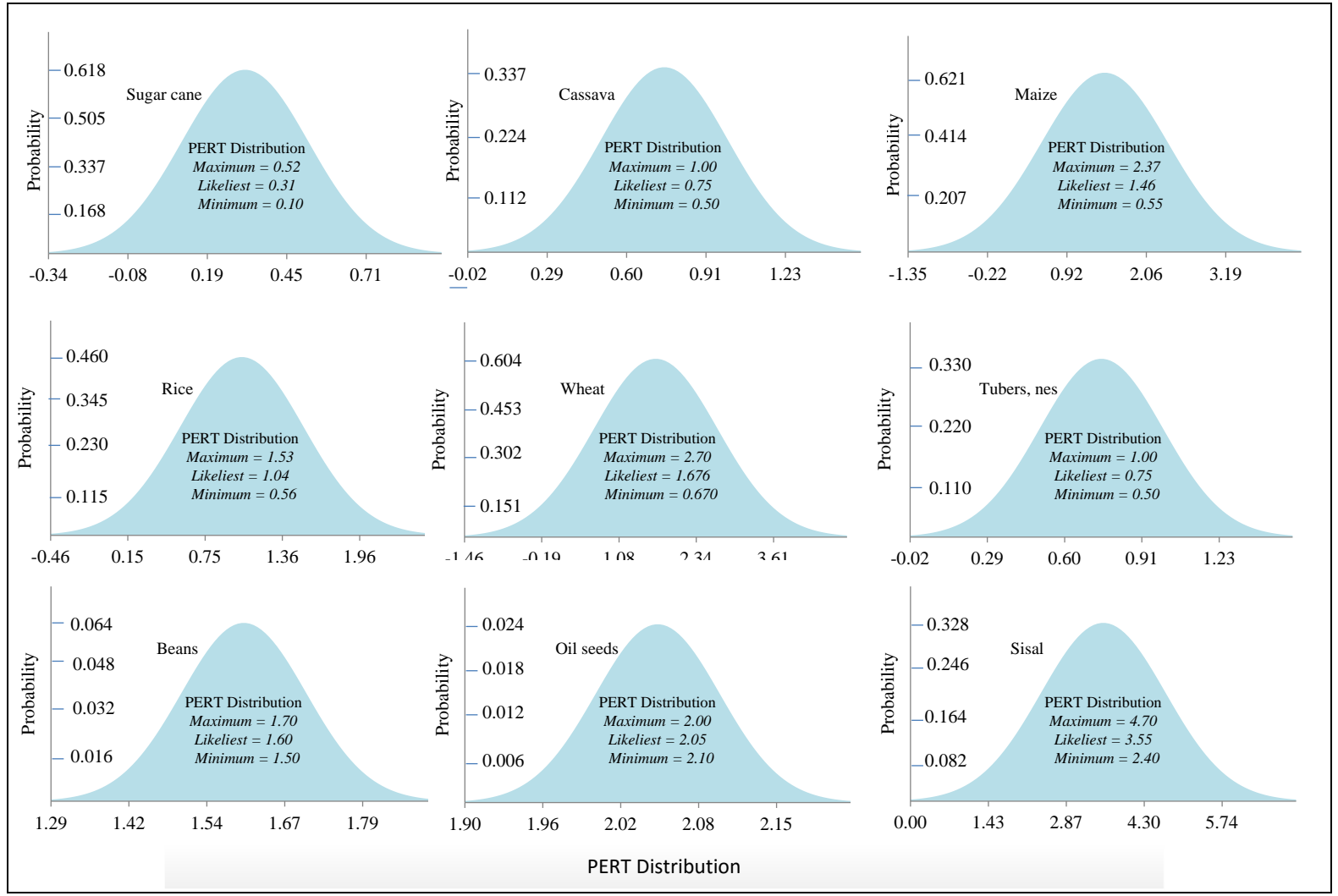

Figure 2: Probability distribution of crop residues for different crops in Tanzania

\subsubsection{Computation of energy potential of animal wastes}

Animal waste refers to livestock garbages such that the quantity of wastes produced depends on the amount of fodder consumed, fodder quality and animal weight. Considering the limited number of studies conducted to estimate the energy potential of animal wastes in africa, the energy potential of animal wastes was calculated according to the method proposed by Kemausuor et al. (2014) with the assumption that the quantity of manures produced ( $\mathrm{kg} /$ day) by livestock in Ghana is equivalent to that in Tanzania. Though this assumption is not always valid to all geographical locations but can provide an indication of the energy potential of animal wastes in Tanzania.

\section{RESULTS AND DISCUSSION}

\subsection{The amount of crop residues}

The study revealed a significant difference in the quantity of crop residues that can be generated from the ten crops studied in Tanzania from 1961-2012 (Table 2). Sugar cane has been established to have the highest amount of crop residues $(229,817,469.37 \mathrm{~kg} / \mathrm{year})$ followed by cassava which can generate about $59,408,129$ 
INDEPENDENT JOURNAL OF MANAGEMENT \& PRODUCTION (IJM\&P)

http://www.ijmp.jor.br

v. 7, n. 4, October - December 2016

ISSN: 2236-269X

DOI: 10.14807/ijmp.v7i4.473

kg/year of crop residues, while dry beans has the least amount crop resudes generated i.e., 9,343,326.58 kg/year.

Considering the existing strong correlation between the amount of crop residues that can be collected compared to the amount of renewable energy to be generated, great effort has to be given to the exploitation of renewable energies from sugar cane and theafter cassava which is widely grown in many regions of tanzania.

It has been documented that various projects have been initiated to produce clean and safe energy from sisal for several years in tanzania without success (TERRAPON-PFAFF et al. 2012), the findings of this study challenges the energy policy makers and planners to see the possibility of generating clean and safe energy from the sugar cane.

Table 2: Amount of crop residues generated from crop yields

\begin{tabular}{lrrr}
\hline Crop & Yield (kg/year) & RPR & Crop residues (kg/year) \\
\hline Wheat & $14,145,327.12$ & 1.678 & $23,735,858.90$ \\
Rice, paddy & $15,386,186.92$ & 1.04 & $16,001,634.40$ \\
Maize & $12,501,760.77$ & 1.46 & $18,252,570.72$ \\
Cassava & $79,210,839.23$ & 0.75 & $59,408,129.42$ \\
Tubers, nes & $20,379,872.14$ & 0.75 & $15,284,904.11$ \\
Sugar cane & $741,346,675.38$ & 0.31 & $229,817,469.37$ \\
Beans dry & $6,456,299.23$ & 1.6 & $10,330,078.77$ \\
Seed cotton & $4,956,671.92$ & 1.885 & $9,343,326.58$ \\
Oil seeds, nes & $5,843,554.81$ & 2.05 & $11,979,287.36$ \\
Sisal & $6,586,075.96$ & 3.55 & $23,380,569.66$ \\
\hline
\end{tabular}

\subsection{The energy potential of crop residues}

Based on the average biomass yield from different crops and conversion efficiency i.e., thermal values of each type of crops grown, the energy potential of crop residues of tanzania from 1961-2012 has been estimated. The results revealed that the total bioenergy potential of crop residues in Tanzania reached 5,714 $\mathrm{TJ}$ in 2012 (Table 3), which is extremely larger than the installed electric energy generation capacity (1564 MW) of TANZANIA in 2013 (GERMAN ENERGY DESK, 2013).

In addition, the results indicated that sugar cane has the highest energy potential $(2,966.4 \mathrm{TJ} /$ year), followed by cassava with the renewable energy potential of $845 \mathrm{TJ} / \mathrm{year}$, while seed cotton has the lowest energy potential (148.4 TJ/year). So the difference in energy potential of various crop residues provides a sign of priority areas for the energy investments in Tanzania. 
INDEPENDENT JOURNAL OF MANAGEMENT \& PRODUCTION (IJM\&P)

http://www.ijmp.jor.br

v. 7, n. 4, October - December 2016

ISSN: 2236-269X

DOI: 10.14807/ijmp.v7i4.473

Besides, the results have demonstrated the need for the government to exploit the available crop residues since even crops with the least energy generation capacity e.g., seed cotton (Table 3) can remove completely the existing problem of the energy access in the rural areas of tanzania and support the governments' efforts of turning our economy into industrialized economy.

Table 3: Energy potential of crop residues available in Tanzania

\begin{tabular}{|c|c|c|c|c|c|}
\hline Crop & $\begin{array}{r}\text { Crop residues } \\
\text { (kg/year) }\end{array}$ & $\begin{array}{r}\text { Conversion } \\
\text { ratio }^{\mathrm{a}}\left(\varepsilon_{\mathrm{i}}\right)\end{array}$ & $\begin{array}{r}\text { Equivalent } \\
\text { standard coal } \\
(\mathrm{kg} / \text { year })\end{array}$ & $\begin{array}{r}\text { Energy potential } \\
\text { (mj/year) }\end{array}$ & $\begin{array}{r}\text { Energy } \\
\text { potential } \\
\text { (tj/year) }\end{array}$ \\
\hline Wheat & $23,735,858.9$ & 0.500 & $11,867,929.4$ & $347,374,295.0$ & 347.3 \\
\hline Rice, paddy & $16,001,634.4$ & 0.429 & $6,864,701.1$ & $200,929,802.9$ & 200.9 \\
\hline Maize & $18,252,570.7$ & 0.529 & $9,655,609.9$ & $282,619,702.1$ & 282.6 \\
\hline Cassava & $59,408,129.4$ & 0.486 & $28,872,350.9$ & $845,093,710.8$ & 845.0 \\
\hline Tubers, nes & $15,284,904.1$ & 0.486 & $7,428,463.3$ & $217,431,123.6$ & 217.4 \\
\hline Sugar cane & $229,817,469.3$ & 0.441 & $101,349,503.9$ & $2,966,499,982.0$ & $2,966.4$ \\
\hline Beans dry & $10,330,078.7$ & 0.543 & $5,609,232.7$ & $164,182,243.2$ & 164.1 \\
\hline Seed cotton & $9,343,326.5$ & 0.543 & $5,073,426.3$ & $148,499,188.7$ & 148.4 \\
\hline Oil seeds, nes & $11,979,287.3$ & 0.529 & $6,337,043.0$ & $18,548,5248.9$ & 185.4 \\
\hline Sisal & $23,380,569.6$ & 0.521 & $12,181,276.7$ & $356,545,971.8$ & 356.5 \\
\hline
\end{tabular}

\subsection{The energy potential of animal wastes}

Over the past several decades, animals were considered to be the main source of nutrients to human being and soil fertility with a little attention to the energy potential of their wastes. The present study revealed a significant contribution of animal wastes to the tanzania electric energy grid such that a total of $1397 \mathrm{TJ}$ of energy could be generated from the live animals in 2012 (Table 4).

Table 4: Energy potential of animal wastes available in TANZANIA

\begin{tabular}{lrrrrrrr}
\hline Animal & $\begin{array}{r}P_{\text {live }} \\
(\text { heads) }\end{array}$ & $\begin{array}{r}Y_{\operatorname{man}} \\
(\mathrm{kg} / \mathrm{head} / \mathrm{d})^{\mathrm{b}}\end{array}$ & $\eta^{\mathrm{b}}$ rec & $\begin{array}{r}\mathrm{C}_{\mathrm{ts}} \\
(\mathrm{gts} / 100 \mathrm{~g})^{\mathrm{b}}\end{array}$ & $\begin{array}{r}\text { Biogas } \\
\left(\mathrm{m}^{3} / \mathrm{d}\right)\end{array}$ & $\begin{array}{r}\text { Biogas } \\
\left(\mathrm{m}^{3} / \mathrm{year}\right)\end{array}$ & $\mathcal{E}_{\mathrm{n}}(\mathrm{MJ} / \mathrm{year})$ \\
\hline Cattle & 1368174 & 12 & 0.2 & 12 & 86687544 & 31640953680 & 1139074332 \\
Sheep & 3541011 & 1.2 & 0.2 & 25 & 4674135 & 1706059373 & 61418137 \\
Goats & 8350005 & 1.5 & 0.2 & 25 & 13777509 & 5028791000 & 181036476 \\
Pigs & 280786 & 3.6 & 0.5 & 11 & 1223104 & 446433072 & 16071590 \\
Poultry & 10874 & 0.02 & 0.5 & 25 & 598 & 218313 & 7859 \\
\hline
\end{tabular}

Source: Fao (2015) and kemausuor et al. (2014)

The number of live animals ( $\left.p_{\text {live }}\right)$, manure production $\left(y_{\text {man }}\right)$, solid concentration $\left(c_{\mathrm{tc}}\right)$, recovery $\left(\eta_{\mathrm{rec}}\right)$, methane conversion factor $(\mu)\left(0.036 \mathrm{GJ} / \mathrm{m}^{3}\right)^{\mathrm{b}}$, biomethane potential $\left(y_{\mathrm{bmp}}\right) \mathrm{m}^{3} / \mathrm{kgts}(0.22)^{\mathrm{b}}$ and energy potential $\left(\varepsilon_{\mathrm{n}}\right)$.

Out of the five live animals kept in Tanzania, cattle was found to have the highest energy potential $(1,139,074,332 \mathrm{MJ} /$ year), followed by goats with the energy 
INDEPENDENT JOURNAL OF MANAGEMENT \& PRODUCTION (IJM\&P)

http://www.ijmp.jor.br

v. 7, n. 4, October - December 2016

ISSN: 2236-269X

DOI: 10.14807/ijmp.v7i4.473

potential of $181,036,476 \mathrm{MJ} /$ year while poultry has the lowest energy potential of $7859 \mathrm{MJ} / \mathrm{year}$. The findings have demonstrated that, the existing problem of energy access to many regions of Tanzania can be eliminated completely if more priority will be given to energy generation from crop residues and animal wastes so long as the amount of animal wastes required for the soil fertility and animal feed is maintained.

In addition, the results awakes policy makers and energy planners to restore the biogas production plants that were built in various manufacturing industries and community centres such as CAMATEC in ARUSHA and Minja Ufundi in Mwanga Districts of Tanzania just to mention a few.

\section{CONCLUSION}

The amount of crop residues, animal wastes, energy potential of crop residues and animal wastes have been evaluated and quantified. The results demonstrated that proper utilization of crop residues and animal wastes for the generation of renewable energy in rural and urban areas of Tanzania can increase significantly energy access and reduce fossil energy consumption. Besides, appropriate use of crop residues and animal wastes for the energy generation has great contribution towards improved livelihood of rural population, human health and alleviation of the global warming.

\section{ACKNOWLEDGEMENT:}

This study was supported by VRIL-UOS/IUC - Mzumbe University, Project 3: Natural Resources Management.

\section{REFERENCES}

BENTSEN, N. S.; FELBY, C.; THORSEN, B. J. (2014) Agricultural residue production and potentials for energy and materials services. Progress in energy and combustion science, n. 40, p. 59-73.

BI, Y. Y.; WANG, Y. J.; GAO, C. Y. (2010) Straw resource quantity and its regional distribution in china. $\mathbf{J}$ agric mech res. $n$. 3, p. 1-7.

BI, Y. Y.; GAO, C. H. Y.; WANG, Y. J.; LI, B. Y. (2009) Estimation of strew resources in China. Trans csae. n. 25, p. 211-217.

BIOMASS ENERGY EUROPE (2010) Staus of biomass resource assessments version $\quad 3 . \quad H t t p: / / w w w . e u-b e e$. info/getitem.asp?item=digistorefile;247973; 837\&params=open;gallery. (accessed on: may 2015.

BLANCO, C. H.; LAL, R. 2009). Crop residue removal impacts on soil productivity and environmental quality. Crit rev plant sci. n. 28, p. 139-63. 
INDEPENDENT JOURNAL OF MANAGEMENT \& PRODUCTION (IJM\&P)

http://www.ijmp.jor.br

v. 7, n. 4, October - December 2016

ISSN: 2236-269X

DOI: 10.14807/ijmp.v7i4.473

COOPER C. J.; LAING C. A. (2007) A macro analysis of crop residue and animal wastes as a potential energy source in africa. J energy south afr. $n$. 18, p. 10-19.

DEBOYS, J. (2004) Decision pathways in patent searching and analysis. World patent inform. n. 26, p. 83-90.

DUKU, M. H.; GU, S.; HAGAN, E. B. (2011) A comprehensive review of biomass resources and biofuels potential in Ghana. Renewable and sustainable energy reviews, n. 15, p. 404-415.

FAO (2015) Faostat-agriculture, food and agriculture organisation of the united nations, fao, 2015. Http://faostat.fao.org/. (accessed on: march 2015).

FELIX, M.; GHEEWALA, S. H. (2011) A review of biomass energy dependency in Tanzania: $9^{\text {th }}$ eco-energy and materials science and engineering symposium. Energy procedia, n. 9, p. 338-343.

FERREA, A. J. C.; VELÁZQUEZ-MARTÍ, B.; LÓPEZ-MARTÍNEZA, J. A.; MANZANO-AGUGLIARO, F. (2011) Greenhouse crop residues: energy potential and models for the prediction of their higher heating value. Renewable and sustainable energy reviews, n. 15, p. 948-955.

GEHRUNG, J.; SCHOLZ, Y. (2009) The application of simulated npp data in improving the assessment of the spatial distribution of biomass in Europe. Biomass bioenergy, n. 33, p. 712-720.

GERMAN ENERGY DESK (2013) Target market study tanzania solar pv \& wind power. Report by the delegation of german industry and commerce in kenya.

GÓMEZ, A.; RODRIGUES, M.; MONTAÑÉS, C.; DOPAZO, C.; FUEYO, N. (2010) The potential for electricity generation from crop and forestry residues in Spain. Biomass bioenergy 34, 703-719.

HOU, G., LI, Y. B., XI, J. C., YANG, G. H., LUO, S. F. (2009) Differentiation evaluation on regional suitability of crop straw resources utilization in china. Agric res arid areas. n. 27, p. 189-196.

HU, Y. A.; CHEN, H. F. (2013) Development and bottlenecks of renew-able electricity generation in china: a critical review. Environ sci technol. n. 47, p. 30443056.

ISMAIL, Z.; KHEMBO, P. (2015) Determinants of energy poverty in South Africa. Journal of energy in southern Africa, v. 26, n. 3, p. 66-78.

JIANG, D.; ZHUANG, D.; FU, J.; HUANG, Y.; WEN, K. (2012) Bioenergy potential from crop residues in China: availability and distribution. Renewable and sustainable energy reviews, n. 16, p. 1377- 1382.

JONES, R. (2008) Financial risk in practice based commissioning. Br j healthcare manag. n. 14, p. 199-204.

KEMAUSUOR, F.; KAMP, A.; THOMSEN, S. T.; BENSAH, E. C.; ØSTERGÅRD, H. (2014) Assessment of biomass residue availability and bioenergy yields in ghana. Resource conservation and recycling, n. 86, p. 26-37.

MONFORTI, F.; LUGATO, E.; MOTOLA, V.; BODIS, K.; SCARLAT, N.; ALLEMAND, J. F. (2015) Optimal energy use of agricultural crop residues preserving soil organic carbon stocks in europe. Renewable and sustainable energy reviews, n. 44, p. 519-529. 
INDEPENDENT JOURNAL OF MANAGEMENT \& PRODUCTION (IJM\&P)

http://www.ijmp.jor.br

v. 7, n. 4, October - December 2016

ISSN: 2236-269X

DOI: 10.14807/ijmp.v7i4.473

MONFORTI, F.; BÓDIS, K.; SCARLAT, N.; DALLEMAND, J. F. (2013) The possible contribution of agricultural crop residues to renew able energy targets in Europe: a spatially explicit study.

MORENOA, J. M. V.; CALLEJÓN-FERREA, A. J.; PÉREZ-ALONSOA, J.; VELÁZQUEZ-MARTÍ, B. (2012) A review of the mathematical models for predicting the heating value of biomass materials. Renewable and sustainable energy reviews, n. 16, p. 3065-3083.

NZILA, C.; DEWULF, J.; SPANJERS, H.; KIRIAMITI, H.; VAN LANGENHOVE, H. (2010) Biowaste energy potential in Kenya. Renewable energy, 35, p. 2698-2704.

OKELLO, C.; PINDOZZI, S.; FAUGNO, S.; BOCCIA, L. (2013) Bioenergy potential of agricultural and forest residues in uganda. Biomass and bioenergy, n. 56, p. 515525.

RAYA, S.; GHOSHA, B.; BARDHAN, S.; BHATTACHARYYA, B. (2016) Studies on the impact of energy quality on human development index. Renewable energy, $\mathrm{n}$. 92, P. 117-126.

SCARLAT, N.; MARTINOV, M.; DALLEMAND, J. F. (2010) Assessment of the availability of agricultural crop residues in the European Union: potential and limitations for bioenergy use. Waste manag. n. 30, p. 1889-1897.

SHEYA, M. S.; MUSHI, S. J. S. (2000) The state of renewable energy harnessing in tanzania. Applied energy, n. 65, p. 257-271.

SONG, G.; CHE, L.; YANG, Y.; LYAKURWA, F.; ZHANG, S. (2014). Estimation of crop residue in China based on a Monte Carlo analysis. Chinese Journal of Population, Resources and Environment, 12(1), 88-94.

TAULO, J. L. (2015) Energy supply in Malawi: options and issues. Journal of energy in Southern Africa 26(2), 19-32.

TERRAPON-PFAFF, J.; FISCHEDICK, M.; MONHEIM, H. (2012) Energy potentials and sustainability - the case of sisal residues in Tanzania. Energy for sustainable development, v. 16, n. 3, P. 312-319.

USDA (2006) Crop residue removal for biomass energy production: effects on soils and recommendations. Agronomy technical note n. 19; 2006, http://soils.usda.gov/sqi/management/files/sqatn19.pdf (accessed on: february, 2016).

WEC (2015) the 2015 world energy issues monitor: energy price volatility, the new normal. World energy council (WEC), p. 62-64 Cornhill, London, United Kingdom.

WOINAROSCHY, A. (2008) Cost sensitivity analysis by monte carlo simulation. Environ eng manag j. n. 7, p. 173-177.

ZHAO, Z-Y.; CHENA Y-.; CHANG, R-D. (2016) How to stimulate renewable energy power generation effectively? - china's incentive approaches and lessons. Renewable energy, n. 92, p. 147-156. 